\title{
Proceeding
}

Supplementary Issue: Autumn Conferences of Sports Science. Costa Blanca Sports Science Events, 18-19 December 2020. Alicante, Spain.

\section{An experimental didactic path to "re-educate to values" through motor and sports practice}

\author{
DAVIDE DI PALMA \\ Parthenope University, Naples, Italy
}

\begin{abstract}
Physical and sports practice, to date, is called to explode all its educational potential both in formal and nonformal training contexts. This assumption takes on even more importance when the pedagogical and training action must be aimed at critical social contexts. In order to achieve this task, it is essential to structure didactic strategies that convey motor and sports activities towards the pursuit of educational-pedagogical objectives. In this regard, this research work proposes an experimental didactic path aimed at subjects who have experienced social deviance phenomena, and oriented towards their "re-education to values".

Keywords: Innovative didactics; Re-Educate to values; Motor education; Sports education; Social deviance phenomena; Experimental didactics.

Cite this article as:

Di Palma, D. (2021). An experimental didactic path to "re-educate to values" through motor and sports practice. Journal of Human Sport and Exercise, 16(2proc), S259-S268. doi:https://doi.org/10.14198/jhse.2021.16.Proc2.11
\end{abstract}

Corresponding author. Parthenope University, Naples, Italy. https://orcid.org/0000-0001-8224-5797

E-mail: davide.dipalma@uniparthenope.it

Abstract submitted to: Autumn Conferences of Sports Science. Costa Blanca Sports Science Events, 18-19 December 2020. Alicante, Spain.

JOURNAL OF HUMAN SPORT \& EXERCISE ISSN 1988-5202

(c) Faculty of Education. University of Alicante

doi:10.14198/jhse.2021.16.Proc2.11 


\section{INTRODUCTION}

When analysing the role of motor and sports education in society, the tendency is to often emphasize either the physical and performance aspects or the purely recreational ones, without considering the huge educational potential of this practice. It also seems reductive to consider as axiomatic the positive function that game, body and movement have in humans at all ages of life, without ever clarifying how this really works and how it is possible to convey this tool in a pedagogical key. Therefore, it is necessary to start from the concept that motor and sports education represents a set of interventions able to modify the individual's behaviours concretely, in order to promote a values-learning process useful for his or her personal formation and for the management of the socio-relational dynamics established with other individuals and with the environment in which he or she lives (Coco, 2014; Holt, Deal \& Pankow, 2020; Quennerstedt, Öhman \& Armour, 2014; Sibilio, 2005). Thus, it is possible to ascribe to it a great ability to convey values, including cooperation, psycho-physical well-being, solidarity, socialization, self-control and many others (Bertagna, 2004; Di Palma, Ascione \& Peluso Cassese, 2017; Farinelli, 2005; Isidori \& Fraile, 2008); In addition, there is a strong belief that it can assume the role of "antidote" to specific social dangers, such as drug use, delinquency, prevention of discomfort and many others, which today represent a constant threat to many people regardless of their individual characteristics. For this reason, motor and sports education is called to fulfil its educational and pedagogical role in the society, both in formal and non-formal educational contexts with particular attention to social environments at risk. The education to values implemented through sport must work on these out-of-line attitudes and behaviours, taking advantage of the game and motor skills to make the student/trainee acquire the values considered fundamental to rediscover his/her role in the community, where he/she can have a correct lifestyle and establish a positive and constructive relationship with others (Bailey, 2006; Mangone, 2016; Maulini, Migliorati \& Isidori, 2017; Sibilio, 2005; Terrone \& Santona, 2012). Motor education in society must therefore take on the task of acting on deviant or out-ofnorm behaviours, preventing and intervening concretely and never abstractly, thus strengthening its pedagogical role in any type of educational context.

Such an action, however, cannot disregard the predisposition of an opportune didactic organization capable of tracing a formative path such as to explode all the educational nature of motor and sports sciences, especially in those critical social contexts. Below, in this regard, is proposed an innovative and experimental educational path based on motor-sports activities implemented in a Social Rehabilitation Community in order to assess the ability to act on the subjects in terms of re-education to values and of socio-pedagogical recovery.

\section{CONTEXT ANALYSIS AND STRUCTURE OF THE EXPERIMENTAL DIDACTIC COURSE}

The purpose was to identify a didactic strategy useful to manage groups of people with behavioural and social problems, and to start a re-educational path for them which contemplated the rediscovery of pedagogical values underlying every individual's formation and social relationships. For this reason, a series of general and specific objectives that the educational path should be able to satisfy were defined.

The general objectives were the following:

- Improving the Affective and Relational Dimension,

- Stimulating participation to involve all the interested subjects,

- Offering a constructive alternative to spend free time to improve current and future lifestyle,

- Using motor and sports activities as a therapeutic means to overcome behavioural and social discomforts. 
As for the specific objectives, the focus was on the educational values of sport to be transferred to everyday life, including:

- Integration and collaboration (recognition of others' difficulties and willingness to help them),

- Socialization,

- Regulation of aggression,

- Respect for rules, others, and oneself,

- Equality (contributing equally to the achievement of a common goal),

- Carrying out and completing a project,

- Acceptance of risk and overcoming of fears,

- Increased confidence in oneself and others.

The project lasted 3 months with 2 weekly meetings of 2 hours each, for a total of 24 meetings and 48 hours of activities; it involved 17 subjects aged between 18-30 years ( 7 women and 10 men) belonging to a Social Rehabilitation Community of the Campania Region, Italy. The Community is located within a green space equipped with outdoor football, basketball and volleyball fields, a swimming pool, a gym equipped with a range of small and large equipment, and several creative laboratories. The users attending the Community are former prisoners and people who had experienced behavioural disorders, alcohol, and drug addiction, and who agreed to undertake a path of social rehabilitation.

From the operational point of view, the project was presented through a preliminary meeting and there was the opportunity to get to know the people to whom the activities were going to be proposed.

The training course was divided into two activities of a motor and sports nature, prepared, and designed in accordance with the project objectives to be pursued and with a specific innovative approach. In fact, the two activities were developed and delivered through a modality that would provide for the application of four innovative teaching techniques among the most recognized ones in the literature, and applicable to motor and sports sciences (Annovazzi et al, 2019; Bearzi \& Colazzo, 2017; Di Palma \& Ascione, 2020; Di Palma \& Belfiore, 2020; Limone, Pace \& Mangione, 2016; Munaro \& Cervellin, 2016):

- Cooperative Learning: in order to stimulate the spirit of collaboration and the awareness that, to achieve the objectives, it needs the contribution of all, promoting a sense of shared responsibility of leadership, encouraging a positive relational climate and the awareness that the success of one depends on the success of the whole group.

- Peer tutoring: employed with the aim of increasing the sense of self-efficacy and self-esteem, while also stimulating everyone's sense of responsibility towards the other members of the peer group.

- Obliquity: employed with the goal of fostering a condition that allows each individual to work at his or her own level, and to experience the success of his or her action. Starting from the assumption that each subject has different skills from the others, this approach tends to create a situation in which everyone is potentially able to overcome the "obstacle", even if operating at different levels of skills, competences, and capabilities.

- Learning-by-emotions: this approach was chosen with the awareness that our brain is able to recognize emotions, and it catalogues and remembers them. In particular, it is the limbic area that defines the connection between the emotion and the context/situation that generated it. This area appears to be strongly connected with the voluntary movements system. Therefore, by proposing motor and sports activities with emotional connotations, we can modify the very learning structure at a neural level, facilitating it and enabling a wider and more stable memorization. 
Considering this, the following table describes the two Activities, entitled:

- Acro gym for All.

- Relaxing with Movement.

Table 1. Didactic activities.

\begin{tabular}{|c|c|c|}
\hline Activity & Description of the Activity Phases & $\begin{array}{l}\text { Innovative Didactic Approach } \\
\text { that characterized the Activity }\end{array}$ \\
\hline $\begin{array}{l}\text { Acro gym } \\
\text { for All }\end{array}$ & $\begin{array}{l}\text { The group acrobatic gymnastics is an innovative activity } \\
\text { as it represents a motor and sport expression for } \\
\text { everyone, and from different points of view, like individual } \\
\text { technical skills, anthropometric characteristics, gifts of } \\
\text { bravery and willingness to take risks; moreover, it } \\
\text { presupposes and stimulates a strong group cohesion, and } \\
\text { develops attention to others and concentration. } \\
\text { Teaching sequence: } \\
\text { 1. Warm-up phase useful for some parts of the body } \\
\text { subsequently stressed (scapular-humeral joint, wrist and } \\
\text { trunk), } \\
\text { 2. Subdivision of the subjects into groups of three or four, } \\
\text { 3. At the beginning, it is advisable that the teacher } \\
\text { establishes the groups formation on the basis of } \\
\text { anthropometric inhomogeneity criteria and of specific } \\
\text { skills, } \\
\text { 4. It is important to pay attention to safety: do not place } \\
\text { students near walls or equipment, provide each group with } \\
\text { mats that create a supporting base and a "safety zone", } \\
\text { after which some photos of the exercises to be performed } \\
\text { are provided via telephone, } \\
5 \text {. The students' work must be carried out without shoes, } \\
\text { both to facilitate the grip of the feet and for safety reasons, } \\
6 . \text { According to the time available, we establish how many } \\
\text { exercises a group will have to carry out, and the groups } \\
\text { will be able to discuss and understand which ones are the } \\
\text { most suitable for their skills. In fact, despite the teacher's } \\
\text { care in forming heterogeneous groups, it will still be very } \\
\text { difficult to obtain truly balanced ones, } \\
\text { 7. Each exercise is distinguished by a "difficulty coefficient" } \\
\text { from } 1 \text { to } 5 \text { assigned by the teacher; each group, after } \\
\text { having tried many exercises, will choose the two it will } \\
\text { propose for the evaluation. } \\
\text { The first mini-block of Lessons (4) were used to test the } \\
\text { basic skills and for a first familiarization with the activity; } \\
\text { the second mini-block of Lessons (5) was entirely aimed } \\
\text { at testing and choosing the exercises, while the last mini- } \\
\text { block ( } 3 \text { ) was dedicated to the final tests with the related } \\
\text { motor and formative evaluations. }\end{array}$ & $\begin{array}{l}\text { Cooperative Learning } \\
\text { Peer tutoring } \\
\text { Obliquity } \\
\text { Learning-by-emotions }\end{array}$ \\
\hline
\end{tabular}




\begin{tabular}{|c|c|c|}
\hline $\begin{array}{l}\text { Relaxing } \\
\text { with } \\
\text { Movement }\end{array}$ & $\begin{array}{l}\text { The principle of muscle contraction-decontraction } \\
\text { relaxation is to relax the body through the perception of the } \\
\text { difference between the state of contraction and } \\
\text { decontraction of the various segments. } \\
\text { The teacher, who proposes and explains the activities, } \\
\text { uses mats and a stereo. } \\
\text { He/she establishes an "agreement" with the students, } \\
\text { which includes not disturbing others and not asking } \\
\text { questions during relaxation. It can be done in any place; } \\
\text { the important thing is that it is cosy and that there is peace } \\
\text { and certainty of not being disturbed. The students lay still } \\
\text { on their back, the teacher asks them to pay attention to } \\
\text { their breathing and close their eyes. Then he/she asks } \\
\text { them to contract their arms and hands isometrically and } \\
\text { strongly for a few seconds, then invites them to relax and } \\
\text { focus on the different pleasantness of the two situations. } \\
\text { In the following phases, he/she asks to contract and } \\
\text { decontract their legs, their face (by grimacing) and finally } \\
\text { their whole body at the same time. In the transition } \\
\text { between one body segment and another, it is appropriate } \\
\text { to continue to remember, the attention to be paid to the } \\
\text { attention. Finally, the teacher guides the muscle toning by } \\
\text { inviting them to move their toes, feet, fingers, hands, and } \\
\text { whole body progressively and calmly. Throughout the } \\
\text { relaxation phase, it is helpful to place music in the } \\
\text { background. Furthermore, it is important that relaxation is } \\
\text { followed by verbalizing the sensations: in this way, the } \\
\text { students understand that they have experienced } \\
\text { something personal but shared with their companions. } \\
\text { The activity was proposed in the } 12 \text { lessons dedicated to } \\
\text { it in a progressive way, until reaching the emotional and } \\
\text { formative involvement of all the students. }\end{array}$ & $\begin{array}{l}\text { Cooperative Learning } \\
\text { Obliquity } \\
\text { Learning-by-emotions }\end{array}$ \\
\hline
\end{tabular}

\section{EDUCATIONAL-PEDAGOGICAL EVALUATION APPROACH OF THE DIDACTIC PROPOSAL}

In order to evaluate the educational effectiveness of the experimental didactic path addressed to subjects experiencing social unrest, a 10-question survey was structured on the basis of the specific objectives chosen in the design phase. This survey was submitted directly to the participants of the educational activity, and the sample analysis was carried out through the creation of an online survey, the link to which was sent to the participants through a WhatsApp group specifically created in order to optimize the operations of dissemination and subsequent data collection. A multiple-choice test mode, which was simple and immediate, was selected, and a score from 1 to 3 was assigned for each answer, where " $1 "$ " represented the minimum value and the "negative" response option, and "3" the maximum value with a totally positive meaning. Once completed the test, the subjects had no feedback regarding the score obtained so that they would not be conditioned. The test was also administered after the intervention to assess any changes attributable to the proposed didactic activities. 
The survey is shown in the following table, where the relative score attributed to each single answer is also highlighted; obviously, this parameter was never made known to the interviewees.

Table 2. Evaluation survey.

Survey

1. What do you think sport and motor activity are?

a) Something useful only to improve fitness

Answers value

b) A simple show to watch to spend some time

c) A chance to connect with people and meet new ones

3

2. Have you ever practiced sports? If yes, how would you define the impact it has had on your life?
a) Negative
b) Indifferent
1
c) Positive
3

3. Do you generally get nervous with others if they make a mistake?
a) Yes, always
b) Often
c) Almost never
3

4. How do you evaluate the role of the Rules within a Society?
a) Useless and Counterproductive
1
b) Useful only in some cases
2
c) Important
3

5. If you notice that another person is in trouble, what do you do?
a) You try to help him/her out
3
b) You inform someone who can help him/her out
2
c) You remain indifferent

6. How do you react when faced with situations that scare you?
a) You avoid them
1
b) You look for someone who can help you out
2
c) You look for the strength to deal with it in yourself
3

7. How much confidence do you have in your abilities?
a) No confidence at all
1
b) Fair confidence
2
c) A lot of confidence

8. How important is your family to you?
a) Not important at all
1
b) Fairly important
2
c) A lot important

9. How open are you to the possibility of meeting new people?
a) Not open at all
1
b) Fairly open
2
c) A lot open
3

10. You have a project that is going the wrong way: how do you deal with that criticality so as to be able to still achieve your goal?

a) You look for someone who can help you out

2

b) You do nothing and forget about it

1 


\section{RESULTS}

The following tables show the outcomes of the survey, measured both before and after the implementation of the experimental didactic program. For each subject participating in the project activity, it was possible to calculate an overall score, given by the sum of the scores obtained for each question, where the minimum value characterizing a negative perspective of the subject in relation to the educational-pedagogical stimuli and objectives of this research was equal to 10 , while the maximum value was 30 . All that said, certainly one of the outcomes to be absolutely taken into account was the differential on the overall score achieved after practicing the didactic activity.

Table 3. Outcomes of the survey in the "pre" experimental didactic activity phase.

\begin{tabular}{llllllllllllll}
\hline Subjects & Gender & Age & Q1 & Q2 & Q3 & Q4 & Q5 & Q6 & Q7 & Q8 & Q9 & Q10 & Score \\
\hline 1 & M & 27 & 2 & 2 & 2 & 2 & 2 & 2 & 2 & 2 & 2 & 2 & 20 \\
2 & $\mathrm{M}$ & 21 & 2 & 2 & 2 & 1 & 2 & 2 & 3 & 2 & 1 & 2 & 19 \\
3 & $\mathrm{M}$ & 30 & 3 & 3 & 1 & 2 & 1 & 1 & 1 & 2 & 2 & 3 & 19 \\
4 & $\mathrm{~F}$ & 22 & 2 & 1 & 3 & 2 & 1 & 3 & 1 & 3 & 1 & 3 & 20 \\
5 & $\mathrm{M}$ & 25 & 1 & 1 & 2 & 2 & 2 & 2 & 3 & 1 & 1 & 2 & 17 \\
6 & $\mathrm{~F}$ & 21 & 2 & 3 & 2 & 2 & 2 & 1 & 2 & 2 & 2 & 3 & 21 \\
7 & $\mathrm{~F}$ & 24 & 2 & 3 & 1 & 2 & 1 & 2 & 1 & 1 & 1 & 1 & 15 \\
8 & $\mathrm{M}$ & 19 & 1 & 2 & 1 & 2 & 3 & 3 & 3 & 1 & 3 & 2 & 21 \\
9 & $\mathrm{M}$ & 20 & 2 & 2 & 2 & 2 & 1 & 1 & 2 & 2 & 2 & 1 & 17 \\
10 & $\mathrm{~F}$ & 18 & 3 & 3 & 2 & 1 & 2 & 2 & 1 & 1 & 1 & 3 & 19 \\
11 & $\mathrm{~F}$ & 29 & 1 & 2 & 3 & 2 & 2 & 1 & 2 & 1 & 1 & 2 & 17 \\
12 & $\mathrm{~F}$ & 27 & 2 & 2 & 2 & 1 & 1 & 2 & 3 & 1 & 2 & 1 & 17 \\
13 & $\mathrm{M}$ & 24 & 2 & 2 & 2 & 2 & 2 & 1 & 2 & 2 & 1 & 2 & 18 \\
14 & $\mathrm{M}$ & 24 & 1 & 1 & 3 & 1 & 1 & 2 & 1 & 1 & 3 & 3 & 17 \\
15 & $\mathrm{M}$ & 28 & 2 & 3 & 2 & 2 & 1 & 2 & 3 & 2 & 2 & 2 & 21 \\
16 & $\mathrm{~F}$ & 22 & 3 & 2 & 3 & 3 & 1 & 2 & 2 & 1 & 1 & 1 & 19 \\
17 & $\mathrm{M}$ & 18 & 1 & 2 & 1 & 1 & 3 & 1 & 3 & 1 & 2 & 3 & 18 \\
\hline
\end{tabular}

Table 4. Outcomes of the survey in the "post" experimental didactic activity phase.

\begin{tabular}{lcccccccccccccc}
\hline Subjects & Gender & Age & Q1 & Q2 & Q3 & Q4 & Q5 & Q6 & Q7 & Q8 & Q9 & Q10 & $\begin{array}{c}\text { Final } \\
\text { Score }\end{array}$ & $\begin{array}{c}\text { Pre-Post } \\
\text { Differential }\end{array}$ \\
\hline 1 & M & 27 & 3 & 3 & 3 & 2 & 3 & 3 & 3 & 2 & 3 & 2 & 27 & 7 \\
2 & $\mathrm{M}$ & 21 & 3 & 3 & 3 & 2 & 3 & 3 & 3 & 3 & 2 & 3 & 28 & 9 \\
3 & $\mathrm{M}$ & 30 & 3 & 3 & 2 & 3 & 2 & 3 & 2 & 2 & 3 & 3 & 26 & 7 \\
4 & $\mathrm{~F}$ & 22 & 3 & 2 & 3 & 2 & 2 & 3 & 2 & 3 & 3 & 3 & 26 & 6 \\
5 & $\mathrm{M}$ & 25 & 2 & 3 & 3 & 2 & 3 & 3 & 3 & 2 & 3 & 2 & 26 & 9 \\
6 & $\mathrm{~F}$ & 21 & 3 & 3 & 3 & 3 & 3 & 2 & 3 & 3 & 3 & 3 & 29 & 8 \\
7 & $\mathrm{~F}$ & 24 & 2 & 3 & 2 & 2 & 2 & 3 & 2 & 2 & 3 & 1 & 22 & 7 \\
8 & $\mathrm{M}$ & 19 & 3 & 3 & 3 & 2 & 3 & 3 & 3 & 2 & 3 & 3 & 28 & 7 \\
9 & $\mathrm{M}$ & 20 & 3 & 3 & 3 & 2 & 2 & 3 & 3 & 3 & 3 & 2 & 27 & 10 \\
10 & $\mathrm{~F}$ & 18 & 3 & 3 & 3 & 3 & 3 & 2 & 3 & 3 & 3 & 3 & 29 & 10 \\
11 & $\mathrm{~F}$ & 29 & 2 & 3 & 3 & 2 & 3 & 2 & 3 & 2 & 3 & 2 & 25 & 8 \\
12 & $\mathrm{~F}$ & 27 & 3 & 3 & 3 & 1 & 3 & 3 & 3 & 2 & 3 & 1 & 25 & 8 \\
13 & $\mathrm{M}$ & 24 & 3 & 3 & 2 & 2 & 1 & 3 & 3 & 2 & 2 & 2 & 23 & 5 \\
14 & $\mathrm{M}$ & 24 & 3 & 2 & 3 & 2 & 3 & 3 & 1 & 3 & 3 & 3 & 26 & 9 \\
15 & $\mathrm{M}$ & 28 & 3 & 3 & 3 & 2 & 3 & 3 & 3 & 2 & 3 & 2 & 27 & 6 \\
16 & $\mathrm{~F}$ & 22 & 3 & 3 & 3 & 3 & 3 & 3 & 3 & 1 & 3 & 1 & 26 & 7 \\
17 & $\mathrm{M}$ & 18 & 1 & 3 & 2 & 2 & 3 & 2 & 3 & 2 & 3 & 3 & 24 & 6 \\
\hline
\end{tabular}


In addition, another outcome brought to light is that of the aggregate data for the entire sample in relation to the answers provided. This makes it possible to observe the variation obtained by the entire group, besides the analysis of each participant.

Table 5. Overall variation in the answers provided by the sample.

\begin{tabular}{lcccccc}
\hline \multirow{2}{*}{ Question } & \multicolumn{2}{c}{ N. of answers with value 1 } & \multicolumn{2}{c}{ N. of answers with value 2 } & \multicolumn{2}{c}{ N. of answers with value 3 } \\
\cline { 2 - 6 } & Pre & Post & Pre & Post & Pre & Post \\
\hline 1 & $5(29.4 \%)$ & $1(5.9 \%)$ & $9(53 \%)$ & $3(17.6 \%)$ & $3(17.6 \%)$ & $13(76.5 \%)$ \\
2 & $3(17.6 \%)$ & $0(0 \%)$ & $9(53 \%)$ & $2(11.8 \%)$ & $5(29.4 \%)$ & $15(88.2 \%)$ \\
3 & $4(23.5 \%)$ & $0(0 \%)$ & $9(53 \%)$ & $4(23.5 \%)$ & $4(23.5 \%)$ & $13(76.5 \%)$ \\
4 & $5(29.4 \%)$ & $1(5.9 \%)$ & $11(64.7)$ & $12(70.6 \%)$ & $1(5.9 \%)$ & $4(23.5 \%)$ \\
5 & $8(47.1 \%)$ & $1(5.9 \%)$ & $7(41.2 \%)$ & $4(23.5 \%)$ & $2(11.8 \%)$ & $12(70.6 \%)$ \\
6 & $6(35.3 \%)$ & $0(0 \%)$ & $9(52.3 \%)$ & $4(23.5 \%)$ & $2(11.8 \%)$ & $13(76.5 \%)$ \\
7 & $5(29.4 \%)$ & $1(5.9 \%)$ & $6(35.3 \%)$ & $3(17.6 \%)$ & $6(35.3 \%)$ & $13(76.5 \%)$ \\
8 & $9(53 \%)$ & $1(5.9 \%)$ & $7(41.2 \%)$ & $10(58.8 \%)$ & $1(5.9 \%)$ & $6(35.3 \%)$ \\
9 & $8(47.1 \%)$ & $0(0 \%)$ & $7(41.2 \%)$ & $2(11.8 \%)$ & $2(11.8 \%)$ & $15(88.2 \%)$ \\
10 & $4(23.5 \%)$ & $3(17.6 \%)$ & $7(41.2 \%)$ & $6(35.3 \%)$ & $6(35.3 \%)$ & $8(47.1 \%)$ \\
\hline
\end{tabular}

\section{CONCLUSIONS}

The research carried out had a series of general and specific objectives that could all be traced back to the desire to stimulate a process of re-education to the values of the person, aimed at subjects involved in social deviance processes. The instrument with which this purpose was pursued was an innovative educational proposal that, through motor and sports sciences, fulfils the educational-pedagogical purpose of taking care of and protecting the formation of the person, regardless of his or her social status, age, and any other individual characteristic.

The proposed educational path showed how motor and sports projects, if carried out in accordance with the principles of didactic-pedagogical sciences, can positively affect deviant behaviour by means of the gamesport and the movement, transmitting important values such as cooperation, equality, socialization, respect for rules and others, and stimulating a correct lifestyle and a good relationship and cooperation with others.

The evaluation process of the educational experimentation carried out, based both on a constant process of field observation and on a survey aimed at investigating the pursuit of the project objectives by the sample, made it possible to bring to light a series of concluding remarks of considerable relevance for the field of pedagogical and social sciences:

- Most subjects reported clear improvements in the affective and relational sphere, showing more willingness to socialize and cooperate.

- Initially, the subjects proved to be more fearful in their approach to the activities, but they later developed greater resourcefulness, due to their increased self-confidence.

- All showed active participation and interest in the proposed activities, understanding that what was proposed could represent a constructive and educational use of their free time.

- After a first phase in which the participants were reluctant to respect the rules established, they understood the importance of putting them into practice autonomously and spontaneously.

- Thanks to the kind of activity carried out, they were able to experience and fully understand the importance of working in groups to achieve a common goal. 
- The innovative didactic approach allowed to stimulate a process of social consciousness evolution, based on the responsibility in the relationship with others.

In addition, it should also be emphasized the pursuit of remarkable outcomes related to motor and sports learning, among which, by means of the field observation, we can find:

- Improved general dynamic coordination,

- Improved balance skills,

- Improved ability to manage the body in unusual situations (like flight, fall, climb),

- Stimulated bodily cooperation with others in the creation of collective motor patterns,

- Refined body perception with a strong awareness of one's own sense of corporeity.

However, both through the field observation phase and the analysis of the outcomes of the survey, it was found that a minority of the sample did not report significant changes; in particular, some subjects showed difficulty in being able to regulate their aggressiveness by trying to prevaricate on others, with little inclination to collaboration and little willingness to help. Nevertheless, the main consideration that sees the didactic tool of motor and sports sciences as a useful tool for the creation and recovery of educational and social values, essential for any individual (especially if subject to a social deviance process), remained unchanged. Surely, however, there is a need for a collective awareness that stimulates a constructive dialogue between the sports realities, schools, communities, and families, in order to establish a sustainable and long-term program based on mutual cooperation, and on the awareness that innovative didactic proposals of motor and sports education shape a fundamental pedagogical dimension in the individual's lifelong learning at any time of his or her life.

\section{REFERENCES}

Annovazzi, C., Camussi, E., Meneghetti, D., Stiozzi, S. U., \& Zuccoli, F. (2019). Orientamento e peer tutoring. Un processo pedagogico innovativo per facilitare e accompagnare l'avvio del percorso universitario. Formazione, lavoro, persona, 25, 201-209.

Bailey, R. (2006). Physical education and sport in schools: A review of benefits and outcomes. Journal of school health, 76(8), 397-401. https://doi.org/10.1111/j.1746-1561.2006.00132.x

Bearzi, F., \& Colazzo, S. (2017). New WebQuest: apprendimento cooperativo, comunità creative di ricerca e complex learning nella scuola di oggi. FrancoAngeli.

Bertagna, G. (Ed.). (2004). Scuola in movimento: la pedagogia e la didattica delle scienze motorie e sportive tra riforma della scuola e dell'università (Vol. 25). FrancoAngeli.

Coco, D. (2014). Pedagogia del corpo ludico-motorio e sviluppo morale (Vol. 2014, pp. 1-224). Anicia.

Di Palma, D, Belfiore, P (2020). Oblique didactics: Innovating the ludic experience in kindergarten to promote pedagogical training. Journal of Human Sport And Exercise, vol. 15(3proc), S531-S538. https://doi.org/10.14198//hse.2020.15.Proc3.06

Di Palma, D., \& Ascione, A. (2020). Experimenting with motor and sports sciences in primary school: Innovative proposals for didactics and evaluation systems. Journal of Human Sport and Exercise, 15(2proc), S162-S172. https://doi.org/10.14198//hse.2020.15.Proc2.06

Di Palma, D., Ascione, A., \& Cassese, F. P. (2017). Gestire lo sport per uno sviluppo educativo. Italian Journal of Educational Research, (18), 59-66.

Farinelli, G. (2005). Pedagogia dello sport ed educazione della persona (Vol. 3). Morlacchi Editore.

Holt, N. L., Deal, C. J., \& Pankow, K. (2020). Positive youth development through sport. Handbook of Sport Psychology, 429-446. https://doi.org/10.1002/9781119568124.ch20 
Isidori, E., \& Fraile, A. (2008). Educazione, sport e valori. Un approccio critico-riflessivo. Rome: Aracne Editor.

Limone, P., Pace, R., \& Mangione, G. R. (2016). Dimensione didattica, tecnologica e organizzativa. La costruzione del processo di innovazione a scuola. FrancoAngeli.

Mangone, E. (2016). Adolescenti e sport. Trasformazioni sociali e pratiche motorie. Milano: FrancoAngeli.

Maulini, C., Migliorati, M., \& Isidori, E. (2017). Sport e inclusione sociale Tra competenze pedagogiche e lavoro di rete Sport and social inclusion Between pedagogical competencies and networking. Rivista Italiana di Pedagogia dello Sport, 2, 33-47.

Munaro, C., \& Cervellin, I. (2016). Peer teaching e inclusione: Da insegnante a insegnante: supporto di rete per la condivisione di competenze educative. Edizioni Centro Studi Erickson.

Quennerstedt, M., Öhman, M., \& Armour, K. (2014). Sport and exercise pedagogy and questions about learning. Sport, Education and Society, 19(7), 885-898. https://doi.org/10.1080/13573322.2013.847824

Sibilio, M. (2005). Lo sport come percorso educativo: attività sportive e forme intellettive. Guida Editori.

Terrone G., Santona A. (2012) II rischio psicopatologico in preadolescenza. Giornale italiano di psicologia, 39(3), 2012, pp.697-706.

\section{@(@) $\Theta \Theta$}

This work is licensed under a Attribution-NonCommercial-NoDerivatives 4.0 International (CC BY-NC-ND 4.0). 